\title{
AGRIBOT-MODEL: COMPACT SOLAR POWERED SPRAYER DEVELOPMENT
}

\author{
Abdelaziz I. Omara*
}

\section{ABSTRACT}

Egyptian agriculture cannot face the modern challenges without introducing local technology to the industry. In this study, agrochemical sprayer robot model powered by photovoltaic solar energy rechargeable cells, was developed and evaluated as a step in this long path. The constructed robot model and its main components, operation software, tests, and final results are described in this work. It was constructed via simple and cost-effective manner. Controlling the robot was achieved through Arduino Bluetooth RC Car mobile application and Bluetooth module HC-06. Arduino C language sequential code was programmed on the microcontroller to allow full control in the robot movement and agrochemicals spray function. The battery was designed to be charged using solar panel. The results of the laboratory tests including: the remote controlling, the programming of the microcontroller unit, the consumed amount of energy by all electric components, the battery performance, the effective working time, and the spray function efficiency are presented. These data were comparable to the theoretical values described in the component's datasheets. This proves the reliability of the robot's design, which qualifies it to be used as is in a prototype production. It can undertake the task of autonomously spraying agrochemicals within greenhouses effectively and safely.

Keywords: robot model, greenhouses, agrochemical spraying, Arduino C language, Bluetooth, solar energy, microcontroller, DC Motor, DC pump, remote control, photovoltaic.

\section{INTRODUCTION}

$\mathrm{M}$ odern farms are expected to produce more yields with higher quality at lower expenses in a sustainable autonomous way. During the next three decades, the agricultural industry will be fronting the challenge of meeting the demands of about 9.8 billion humans predicted in 2050 (King, 2017).

\footnotetext{
* Lecturer at Agricultural and Biosystems Engineering Department, Faculty of Agriculture, Alexandria University, Egypt
} 
Producing more food from less land in a sustainable way cannot be achieved without employment of digital farming and site-specific precision management. Integration of digital tools, sensors ' and control technologies has enhanced developments of agricultural robots (Shamshiri et al., 2018). With the advances in controls theory، applications of these robots in digital farming shift agricultural practices from told fashion tedious operations to continuously automated processes. Research efforts in this extent aiming to develop robots effectively able to perform tedious field tasks have grown significantly in the past decade (Shamshiri and Hameed, 2018).

The environment can be harsh or even deadly to plants, this fact is always in concern of plant production specialists. A greenhouse main function is to maintain the optimal growing conditions to the plants and to increase the yield (Aldrich and Bartok, 1994). During 2017/2018, the Egyptian government inaugurated the first phase of a project to build 100,000 greenhouses in order to face the challenges of climate change, population growth, and water shortage (Egypt's Sisi inaugurates water-preserving national greenhouse project, 2018). The optimal plant growth conditions within the greenhouses encourage unwanted pests which can damage 30$35 \%$ of the yield, making it obligatory to use pesticides and other chemical products that should be sprayed directly on plants (Berenstein and Edan, 2017).

Chemicals are sprayed in specific time periods, making the environment inside greenhouses highly toxic. In addition, the greenhouse temperature, carbon dioxide levels, and humidity are high (Aldrich and Bartok, 1994). As a result, labors in greenhouses always work under stress in uncomfortable and hazardous environment. Traditional manual spraying operations can be harmful to human due to direct exposure to the agrochemical's liquid work environment. In order to reduce that harm, the research and development of plant protecting machine focus on improving the mechanical work efficiency (Deng et al., 2012; Dongare et al., 2017; Berenstein and Edan, 2018).

Spray robot can effectively apply agrochemicals isolate away from direct contact with the human body. Because of the constraints of large 
agricultural robot delicate and complex nature of development, operation, and coast small wireless controlled spray robot can be a rational solution for such challenges (Shamshiri et al., 2018). There were several other trials in this direction during the past decade. Sammons et. al. (Sammons et al., 2005) described a robot that works independently in the spraying of agrochemicals inside the greenhouse with remote control in navigation based on the induction sensors that reveal metal pipes placed under the surface of the soil. However, such design needs special equipped greenhouses and it will not work effectively in normal ones. Patil et. al. (Patil et al., 2017) described a control system for automatic sprayer vehicle which sprays pesticide in any given fields. The system is powered using a solar-powered battery. The Control of the vehicle movement and spraying pesticide is performed through a Bluetooth device. Nevertheless, their concept system was not developed to be applied in a working model or prototype.

Upsurge the Egyptian agriculture industries competitiveness to reduce the importing of machines and technologies in this sector and depends on the local manufacturers. To achieve this, the aim of this work was to develop and to evaluate an agrochemical sprayer robot model powered by photovoltaic solar energy rechargeable cells to eliminate the physical fatigue and the health hazards on humans. That seeks to address some of the health concerns associated with agrochemicals spraying in greenhouses. Following drawbacks of various spraying techniques shows the need of our study.

To evaluate an agrochemical sprayer robot model powered by photovoltaic solar energy rechargeable cells to eliminate the physical fatigue and the health hazards on humans. That seeks to address some of the health concerns associated with agrochemicals spraying in greenhouses. Following drawbacks of various spraying techniques shows the need of our study.

\section{MATERIALS AND METHODS}

\subsection{Robot model design}

Robot model design is consisting of four main parts: a chassis with four motors, a controller unit, a power unit and a sprayer unit. The chassis 
(platform) carries all of the main parts of the robot including electronic hardware, power supplies, electrical pump and the spraying units. Three cameras have been installed to add monitoring and scouting capability to the system. Figure (1) displays the main parts of the robot and all the hardware components.

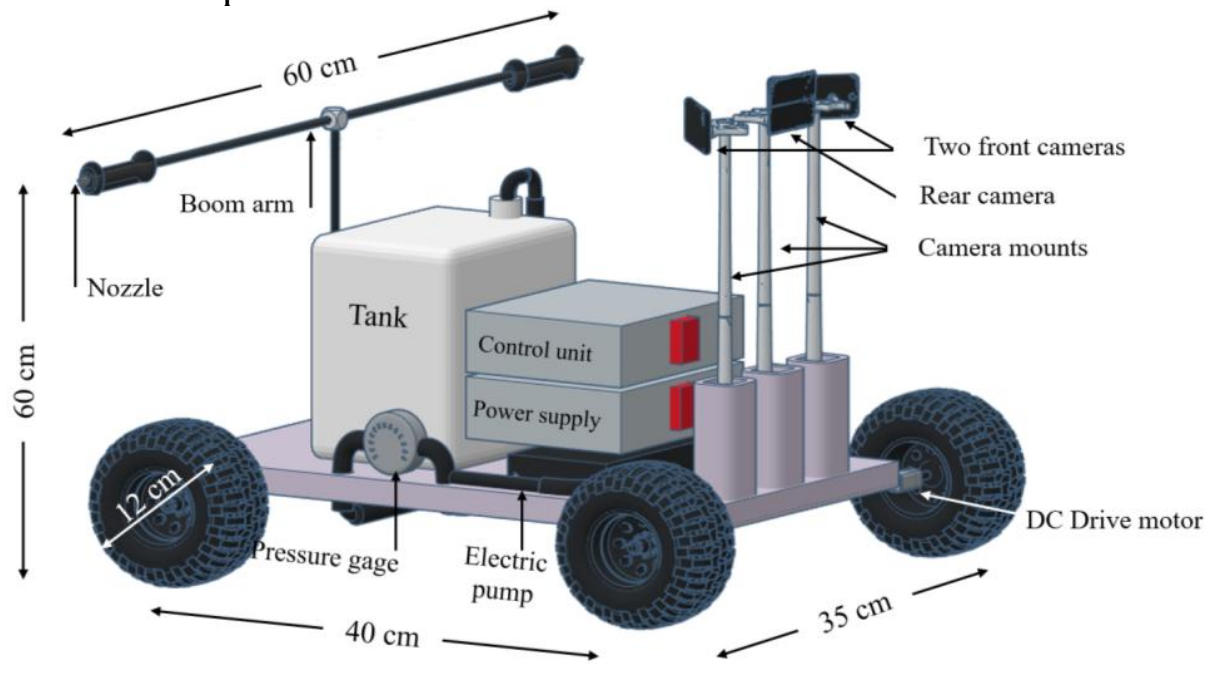

Fig. 1: Main parts and dimensions of the robot model.

Figure (2), illustrates the block diagram of the proposed robot model system and its elements. As can be seen, microcontroller is the main unit of the complete system. Four motors also have been incorporated for controlling the robot movement and directing process in narrow distances. An electric pump is included for spraying purpose.

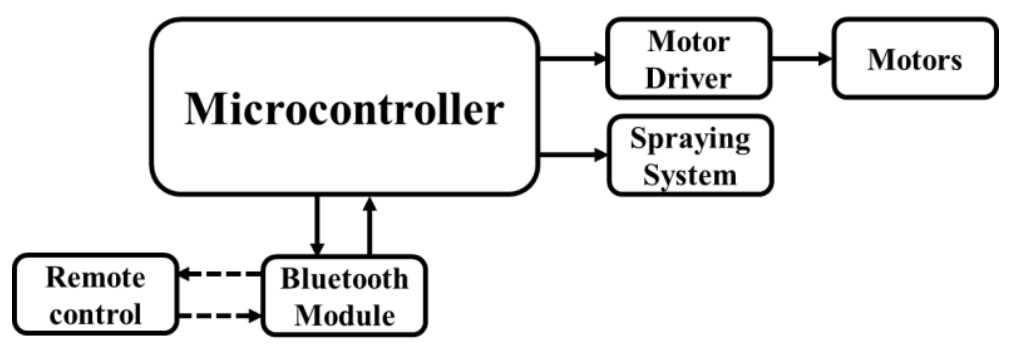

Fig. 2: The block diagram of the proposed system.

The microcontroller is the main unit of the complete system. It consists of two parts, one is transmitter and the other is receiver. The transmitter part 
has a Bluetooth module. The solar panel, Bluetooth and storage battery make the input of the system. The receiver part consists of microcontroller, relays, $L 293 D$ motors, and electric spray pump. The sun rays are collected by the solar cells, where it converts solar energy into electrical energy and it is stored in the battery. It can also use direct solar energy for spraying whereas battery can be used as backup for night time's usage. Bluetooth is used as the communication technology to send instructions to the microcontroller unit, and $L 293 D$ motors. Two relays are used, one to connect the solar panel to the battery and another for the motor of the pump to spray the agrochemicals for the agricultural fields.

\subsection{Hardware details}

The robot model consists of electronic tools and equipment with international standards that are approved and available in the Egyptian market:

- Four DC motors gearbox (12V - $12 \mathrm{~kg} . \mathrm{cm}-210 \mathrm{rpm}$ ) is used for moving and distributing good load balancing to overcome obstacles, in addition to more accuracy in sharp turns (Datasheet 1 ).

- Four "Dagu Wild Thumper" wheels $120 \times 60 \mathrm{~mm}$ (chrome) (Datasheet 2).

- Two drive motor modules $L 298 n$ dual channel used to control the direction of motors and interface the velocity with the microcontroller (Boxall, 2014).

- Microcontroller ATmega328P is used to process the data and send the pulses signals to the driver's modules (Datasheet 3).

- Three lithium battery 4V-2800ma for each one (Datasheet 4).

- PV solar panel (12V, 4.5A, and 24W).

- Charger module, TP4056 (5V-1A) (Datasheet 5).

- Bluetooth module (HC-06) was used to control the robot movement and spraying system from a computer or smartphone (Datasheet 6; Datasheet 7).

- Electric micro spray pump, $12 \mathrm{~V}-15 \mathrm{~W}$ - 6 bar working pressure and 1.5 liter/min flow rate with protective valve type and automatic pressure switch (Datasheet 8).

- Vertical spray booms with two hydraulic nozzles (Klein and Kruger, 2011; Grisso et al., 2013). 
- Bourdon tube pressure gauge, copper alloy, standard version (10 bar), model 111.10, lower mount (radial) (Datasheet 9).

\subsection{Control system}

Figure (3) shows the designed control circuits of the robot model. Icon components of the circuit according to the PROTEUS 7 professional (ISIS User Manual, 2002) and its specifications according to the datasheet of the components are given in Table (1).

\subsection{Driver module}

Four $12 \mathrm{~V}$ DC motors are used to physically run the robot and to navigate it. They were configured in the software and a DC motor drive module called LM298 (Boxall, 2014) is needed to control the speed of the robot by change the value of Pulse Width Modulation (PWM). An Android smartphone is used to control the robot using Bluetooth module $\mathrm{HC}$-06 and 89c2051 microcontroller (Pahuja and Kumar, 2014). Figure (4) shows the connection of the Bluetooth module $\mathrm{HC}-\mathrm{O} 6$ and motor driver with the control circuits of the robot model.

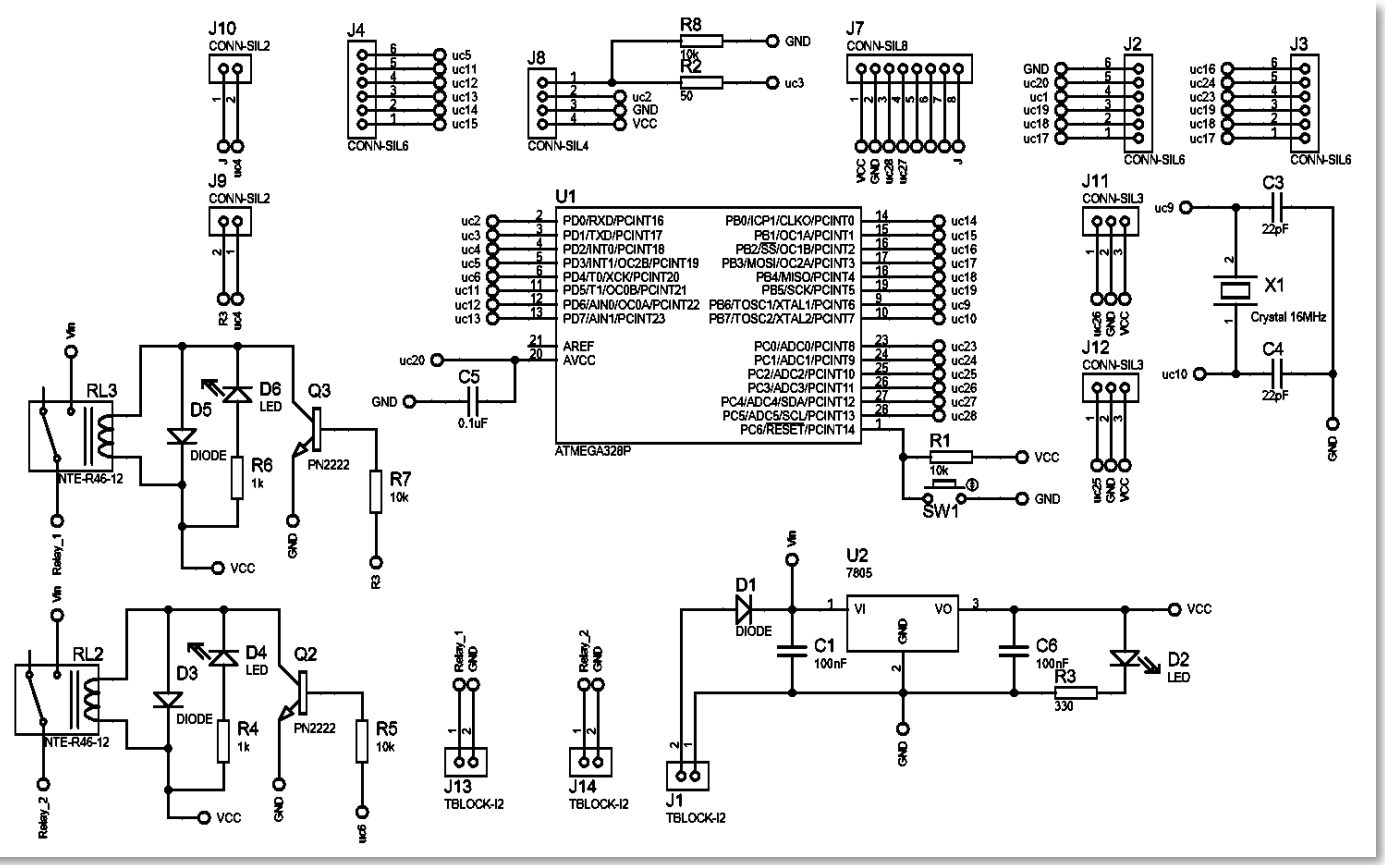

Fig. 3: The robot model control circuits. 
Table 1: Icon components of the robot model control circuits

\begin{tabular}{ll}
\hline Icon & Specifications \\
\hline U1 & Microcontroller ATmega328P. \\
C3 & Crystal 16 Mhz \\
R & Resistors 1k ohm \\
C & Capacitors 100 NF \\
Q & Transistor 2222 \\
L2 & Regulator voltage 5V LM 705 \\
RL & Relay 5V \\
D & Switch bush button \\
SW1 & Diode \\
J7,2,3,8 & Pin output \\
J11,12 & Pin input \\
J13,14 & Output power of relay \\
J1 & Input power of the circuit 12v
\end{tabular}

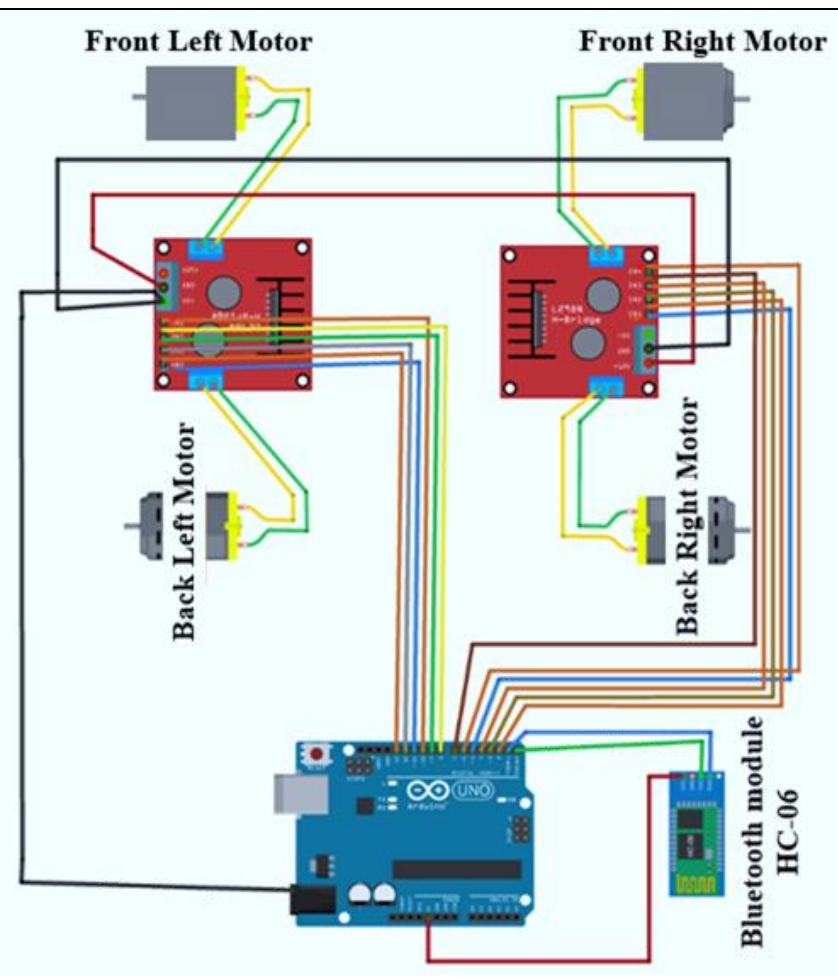

Fig. 4: Connection of the Bluetooth module HC-06 and motor driver with the control circuits of the robot model. 


\subsection{Spray module}

The spray system consists of a small tank with a volume of 4 liters for holding the agrochemicals, Electric spray pump, $12 \mathrm{~V}-15 \mathrm{~W}-6 \mathrm{bar}$ as maximum operating pressure and 1.5 liters/min as maximum flow rate. Two nozzle tips (the standard flat-fan nozzles "11002") were used, and have a 110-degree spray angle and can apply 0.75 liter per minute at rated pressure of 2.75 bar (Grisso et al., 2013). The boom height was fixed at 60 $\mathrm{cm}$, and the distance between the two nozzles is $60 \mathrm{~cm}$. The nozzles are connected to electric micro spray pump which is controlled by the microcontroller.

\subsection{Monitoring system}

Three cameras (two front and one rear) are used for monitoring the operation inside the greenhouse. cameras were used to show and correct the robot's path as well as the targeted and treated areas through the remote control (smartphone). The cameras stream can be watched and/or recorded on a computer. "At Home Camera" application was used to connect the Camera with the computer (iChano Inc., 2018).

\subsection{Robot power system design}

The energy required to operate the robot parts depends on the power consumption for each part. The robot has four DC motors each one needs an electric current $\left(\mathrm{I}_{\mathrm{m}}\right)$ of 1.5 Ampere-hour $(\mathrm{Ah})$ with voltage $\left(\mathrm{V}_{\mathrm{m}}\right)$ of 12 $\mathrm{V}$. Therefore, the energy required to operate the motors $\left(\mathrm{E}_{\mathrm{m}}\right)$ can be computed as follows:

$$
\mathbf{E}_{\mathrm{m}}=\sum \mathbf{I}_{\mathrm{m}} \times \mathbf{V}_{\mathrm{m}}=(4 * 1.5 \mathrm{Ah}) \times 12 \mathrm{~V}=72 \mathrm{Wh}
$$

The robot has an electrical motor sprayer pump that needs an electric current $\left(\mathrm{I}_{\mathrm{p}}\right)$ of 1.25 Ah with voltage $\left(\mathrm{V}_{\mathrm{p}}\right)$ of $12 \mathrm{~V}$. Thus, the energy requirement to operate the pump $\left(\mathrm{E}_{\mathrm{p}}\right)$ can be computed as follows:

$$
E_{p}=I_{p} \times V_{p}=1.25 A h \times 12 \mathrm{~V}=15 \mathrm{Wh}
$$

The total maximum required energy $\left(E_{t}\right)$ can be computed as follows:

$$
E_{t}=E_{m}+E_{p}=72 W h+15 W h=87 W h
$$


Therefore, the total required current $\left(\mathrm{I}_{\mathrm{t}}\right)$ and voltage $\left(\mathrm{V}_{\mathrm{t}}\right)$ are 7.25 Ah and $12 \mathrm{~V}$ respectively.

According to the required operating energy for robot drive motor and sprayer pump, the battery is selected. The power supply system consists of three Lithium Ion battery cells each has a nominal open-circuit voltage $\left(\mathrm{V}_{\mathrm{b}}\right)$ of $4 \mathrm{~V}$ and current $\left(\mathrm{I}_{\mathrm{b}}\right)$ of $2.8 \mathrm{Ah}$. Therefore, the total available energy from the batteries $\left(\mathrm{E}_{\mathrm{b}}\right)$ can be computed as follows:

$$
E_{b}=\sum I_{b} \times V_{b}=2.8 A h \times(3 \times 4 V)=33.3 \mathrm{Wh}
$$

The theoretical battery capacity able to run the robot model for $22 \mathrm{~min}$. Relative reduction in the total run time will depend on the battery state of charge (SOC) value, which ranges between 30 to $50 \%$ (Zhang et al., 2018).

Battery state of charge (SOC) is defined as the remaining capacity of a battery and it is affected by its operating conditions such as load, current and temperature. SOC is a critical condition parameter for battery management. SOC can be calculated as follow (He et al., 2013):

$$
\text { SOC }=\frac{\text { Remaining capacity }}{\text { Rated capacity }}=\frac{\mathbf{V}_{\mathbf{b} 1} \times I_{\mathbf{b} 1}}{V_{\mathbf{b} 2} \times \mathbf{I}_{\mathbf{b} 2}}
$$

The PV solar panel $(12 \mathrm{~V}, 4.5 \mathrm{~A}$, and $24 \mathrm{~W})$ was connected to a charging module TP4056 to charge the three Lithium Ion batteries. The current produced by the solar panel ( $\left.\mathrm{I}_{\mathrm{sp}}\right)$ was calculated by knowing the maximum power of the solar panel $\left(\mathrm{P}_{\mathrm{sp}}\right)$ and the total voltage rating of the battery $\left(\mathrm{V}_{\mathrm{b}}\right)$ that is given by:

$$
I_{s p}=\frac{P_{s p}}{\sum V_{b}}=\frac{24 W}{12 V}=2 \mathrm{~A}
$$

The batteries charging time $\left(\mathrm{T}_{\mathrm{b}}\right)$ was computed by taking the ratio rating of battery in ampere-hour (Ah) to the total current of the solar panel (Amarapur, 2013; Charvani et al., 2017).

$$
\mathbf{T}_{\mathbf{b}}=\frac{\sum \mathrm{I}_{\mathrm{b}}}{\mathrm{I}_{\mathrm{sp}}}=\frac{8.4 \mathrm{~A} \cdot \mathrm{hr}}{2 \mathrm{~A}}=4.2 \mathrm{hr}
$$

The charging procedure is performed at constant voltage with currentlimiting circuitry. The solar panel just used as a charger when batteries 
need to be charged. Figure (5) shows the charger system of the power supplies and the robot power distribution system.

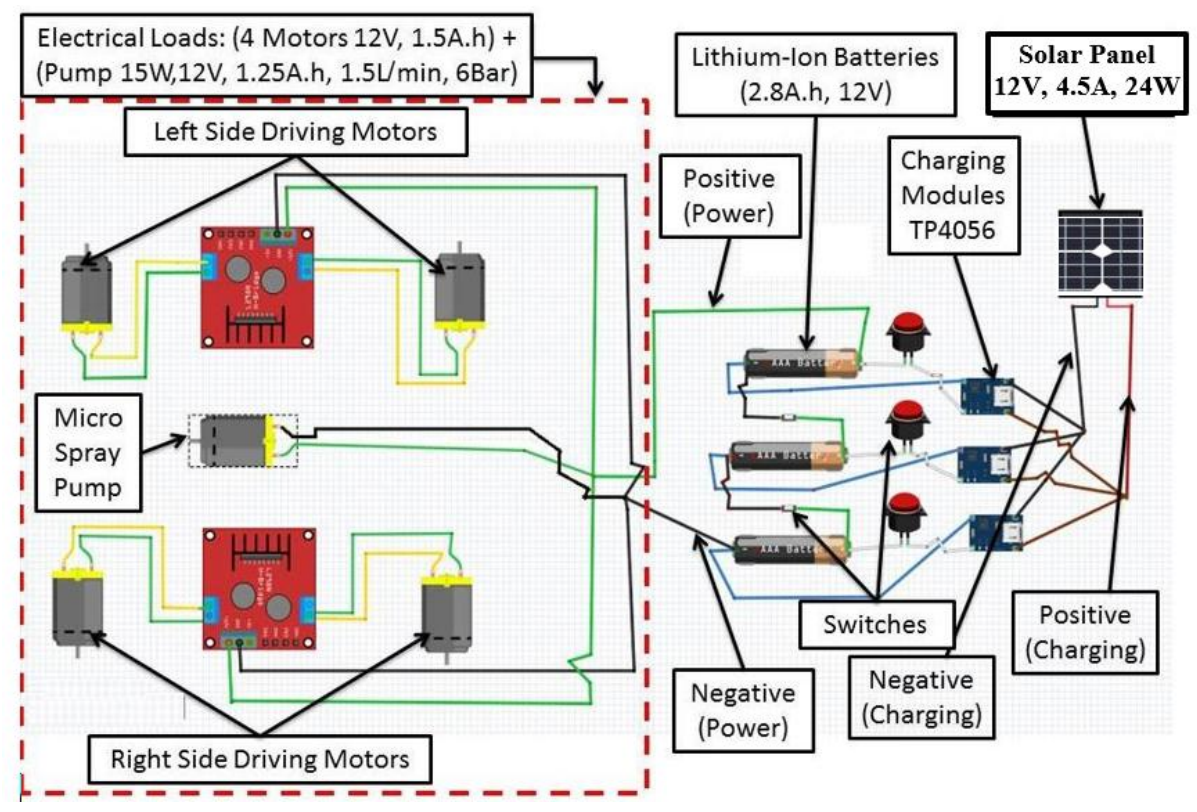

Fig. 5: Robot power distribution circuit.

\subsection{Software details}

\subsubsection{Programming the control system}

Arduino Bluetooth RC Car Android operating system-based application was used to control the robot as described by Yan and Shi (Yan and Shi, 2013). It is offering effective control dashboard with a human-friendly interface. Arduino $\mathrm{C}$ language is used to program the code with interface program Arduino 1.6.8. Figure 6 shows a program flowchart which is used to control all of the robot's functions.

\subsubsection{Robot laboratory functionals test}

The robot was tested in the laboratory at the Department of Agricultural and ${ }^{n}$ vstems Engineering, Faculty of Agriculture, Alexandria University. The test focused on the reliability and functionality of the electrical and electronic circuits as well as the programming of the operations that was implemented by the robot during the evaluation process. The electric current and voltage was measured for battery, movement DC motors, and the electric pump by using the data logger 
module shown in Figure 7a and 7b, also Table 2: Icon components of the data logger module circuit. Simultaneously the following measurements were taken: the robot speed, pump delivery pressure head and discharge of hydraulic spray nozzle, then the percentage of the sprayed area was evaluated.

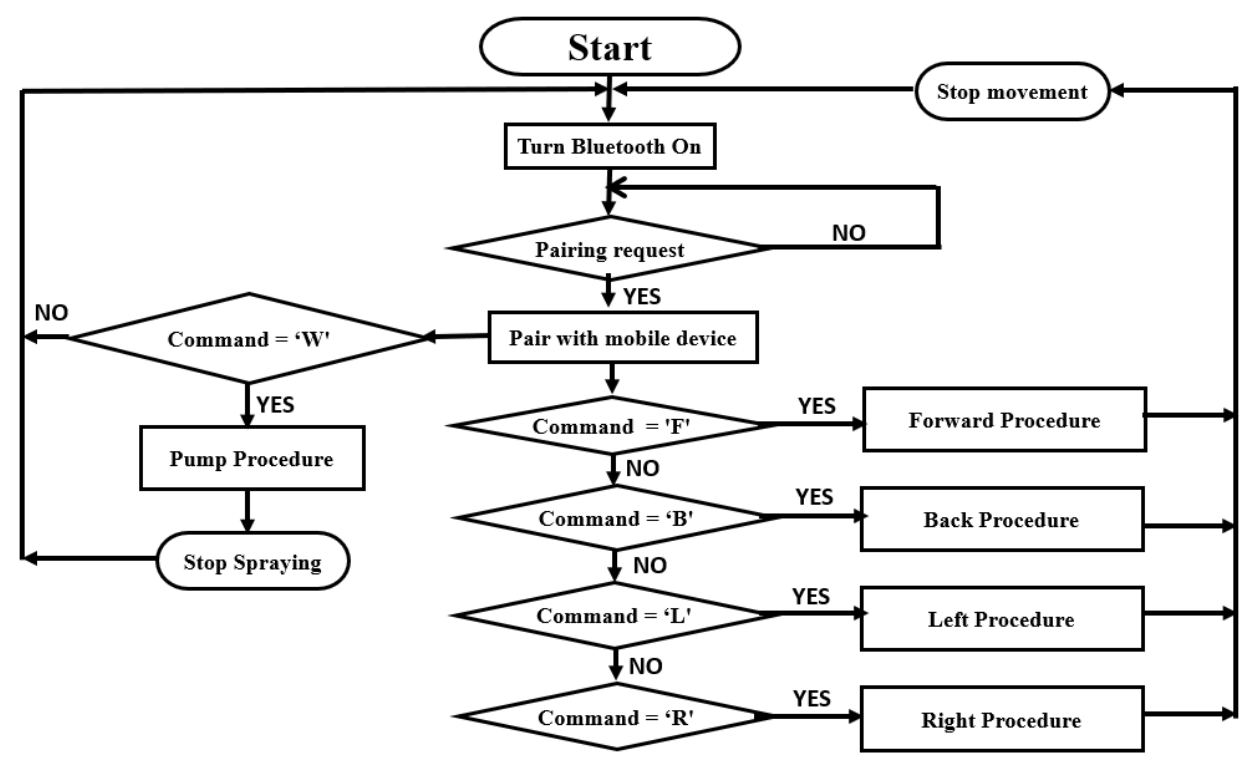

Fig. 6: Robot program flowchart.

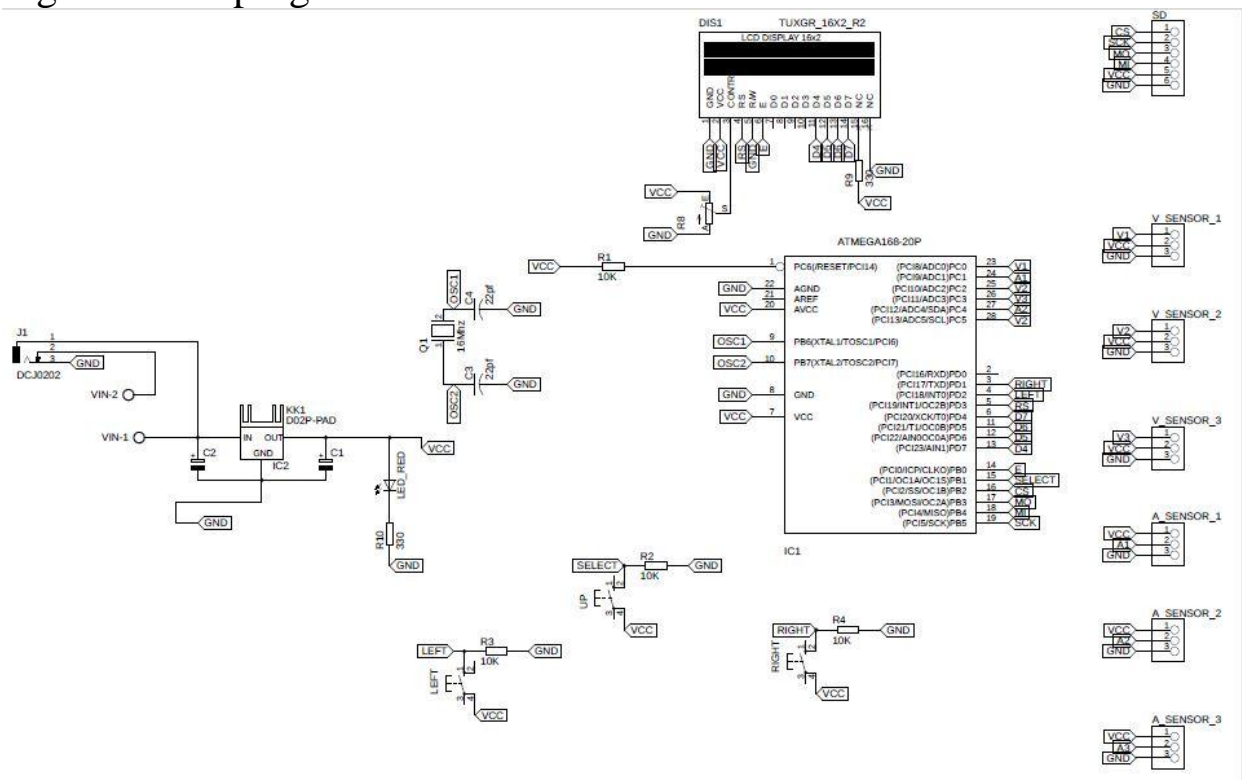

Fig. 7a: Design of voltage and current measurement data logger module. 


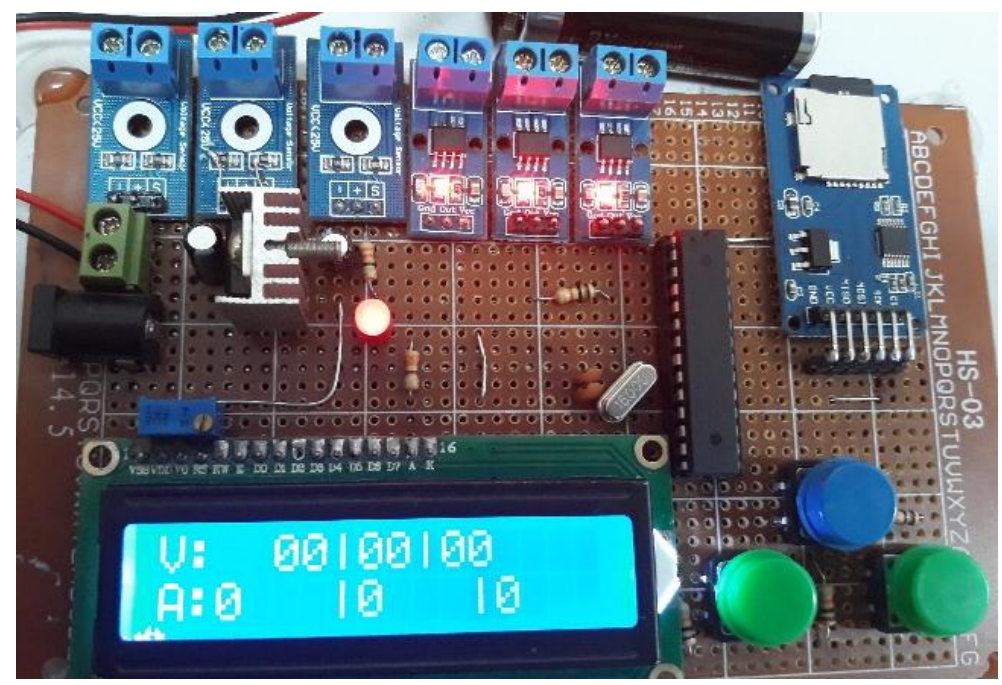

Fig. 7b: Implemented of voltage and current measurement data logger module.

Table 2: Icon components of the data logger module circuit.

\begin{tabular}{ll}
\hline Icon & Specifications \\
\hline IC1 & $\begin{array}{l}\text { Microcontroller Atmega 328p } \\
\text { (Datasheet 3, 2018) }\end{array}$ \\
A_SENSOR_1,A_S & Current Sensor Mosule (ACS712 \\
ENSOR_2,A_SENS & Chip) (Datasheet 8, 2017) \\
OR_3 & \\
V_SENSOR_1,V_S & \\
ENSOR_2,V_SENS & Voltage Sensor Module \\
OR_3 & \\
Q1 & 16 MHz Standard Clock Oscillators \\
KK1 & LM7805 Voltage Regulator (2004) \\
R8 & Potentiometer 10k \\
C3,C4 & 22 Pico Farad \\
LEFT,RIGHT,UP & Push Button \\
DIS1 & LCD Module (Datasheet 10, 2008) \\
SD & SD Card Module \\
LED_RED & LED Red \\
R2,R3,R4 & 10k Resistance \\
R10,R9 & 330 Resistor \\
DCJ0202 & Dc Socket 2.1mm \\
\hline
\end{tabular}

Each experimental test consisted of a single run down to the end of a row $30 \mathrm{~m}$ length and back to the starting point, while spraying blue water from both sides of the robot on white filter paper $(9 \mathrm{~cm} \varnothing)$ at distance of $1.5 \mathrm{~m}$. 
These experiments were repeated until the robot was stopped working because the available battery capacity was not sufficient to operate the robot motors and the spray pump. Also, during each test, the spray tank was fully filled with blue water (4 liters). After every spraying test, four filter papers samples were collected randomly and photographed with a Canon digital camera (SX150 IS). The photographed images then transferred to the Image $\mathbf{J}$ imaging process program used to analysis the spray area for evaluation of the spray quality and uniformity. From each photograph a 1 $\mathrm{cm}^{2}$ area was randomly cropped and analyzed for counting the white and blue pigmented pixels and then the average coverage area was calculated as percentage (Rafiq et al., 2014).

\section{RESULTS AND DISCUSSION}

\subsection{Constructed robot model}

The robot model was built on a chassis made from Acrylic rectangular plate (30 $\mathrm{cm}$ width and $40 \mathrm{~cm}$ length) $5 \mathrm{~mm}$ thickness. This provides strong lightweight platform. All hardware components were mounted and connected as described previously (see above, materials and methods). Figure (8) shows the constructed robot model and its main components. Control and power distribution circuits were implemented according to the design described in Figure $(3 ; 4 ; 5)$. The actual implementation showed in Figure $(9 \mathrm{a}$ and $9 \mathrm{~b})$.

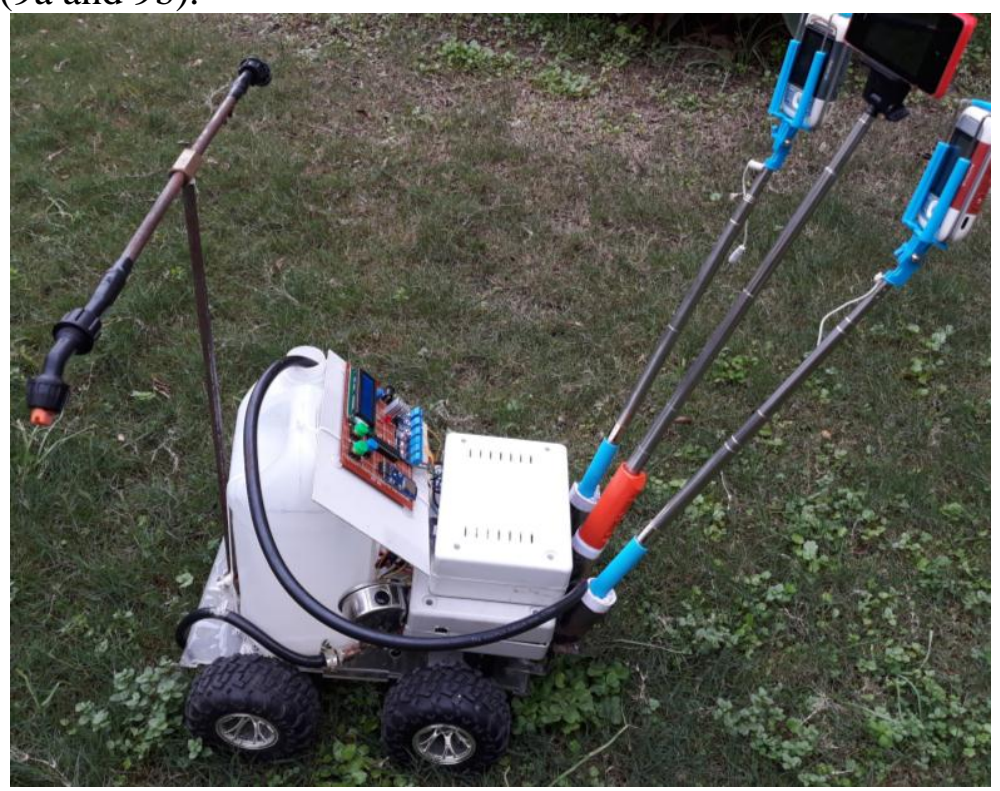

Fig. 8: Robot model sprayer. 


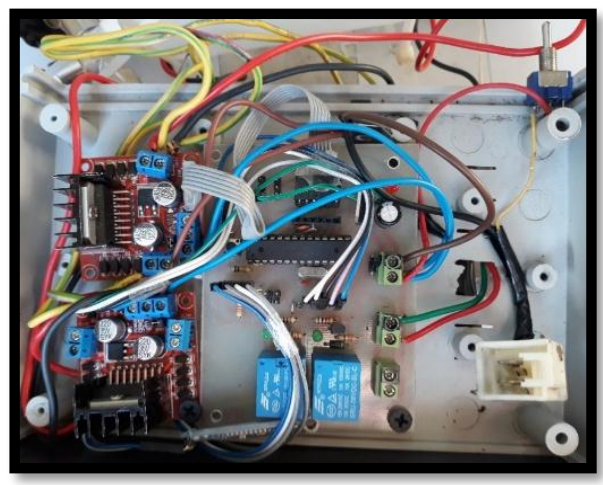

Fig. 9a: Implemented robot model control circuits

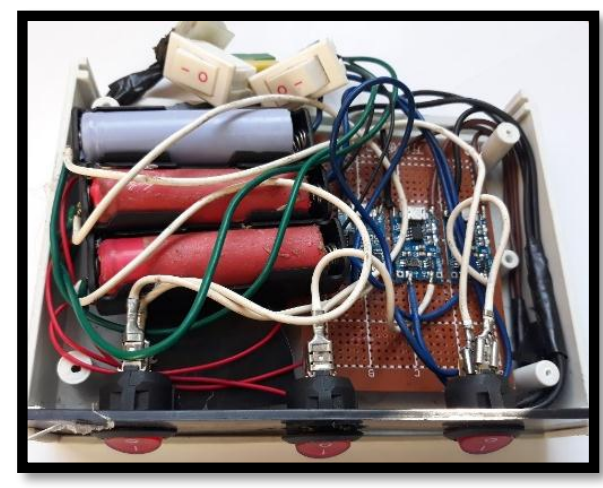

Fig. 9b: Implemented robot power distribution circuit

\subsection{Controlling the robot}

Controlling the robot movement and spray function was achieved through Arduino Bluetooth RC Car mobile application depending on a Bluetooth connection between the smartphone and Bluetooth module HC-06. Arduino C language sequential code was programmed on the microcontroller to allow full control in the robot movement, maneuvering and spray function remotely. In this case, the smartphone acting like a "Remote Control". Activating the remote control through the smartphone were done in two steps as described in the application user manual (Andi Co., 2018): I- Upload code to microcontroller from the program Arduino 1.6.8.; II- Open application RC Car setting and press "connect to car". Then, the following sequence of instructions should be followed:

1. Ensuring active pairing between HC-06 Bluetooth module and an android smartphone.

2. Select paired HC-06 Bluetooth module by clicking on "SELECT DEVICE" in setting and press "CONNECT TO CAR" icon on the mobile app.

3. Once press up-arrow " $\boldsymbol{\Delta}$ " it sends the data "F" to the Bluetooth module connected with the circuit. Subsequently, (Once microcontroller detects "F") the robot moves FORWARD.

4. Once press down arrow " $\nabla$ " it sends the data "B" to the Bluetooth module connected with the circuit. Subsequently, (Once microcontroller detects "B") the robot moves REVERSE. 
5. Once press left-arrow " 4 " it sends the data " $L "$ to the Bluetooth module connected with the circuit. Afterward, (As soon as microcontroller defects "C") the robot turns LEFT.

6. Once press right-arrow " $"$ it sends the data " $R$ " to Bluetooth module connected with the circuit. Afterward, (As soon as microcontroller defects "D") the robot turns RIGHT.

7. Once press STOP "m" key which is located in the center of the remote it sends the data "E" to the Bluetooth module connected with the circuit. Afterward, (As soon as microcontroller defects "E") the robot gets stopped

8. Once press "LEFT CAR" it sends the data "W" to Bluetooth module connected with the circuit. Once the microcontroller detects "W" the sprayer-pump activates, when press "LEFT CAR" once more the spryer-pump deactivates.

9. Click on "DISCONNECT" icon to disconnect paired Bluetooth module.

Figure (10) shows the user interface of the used mobile app.

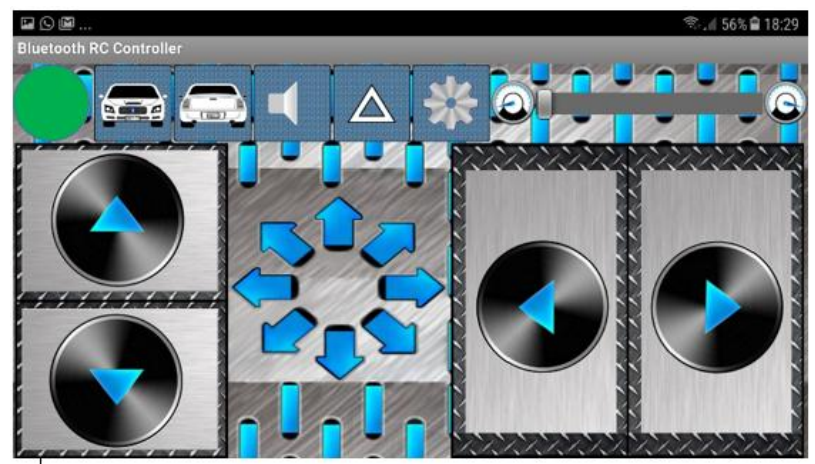

Fig. 10: Arduino Bluetooth RC Car application interface

The agrochemicals spraying function of the robot is controlled remotely through Bluetooth technology, which is expected to achieve better results compared to the previous methods when using human assistance. This would be an automatic mechanical model that would work automatically, powered by solar energy (PV cells) and rechargeable lithium ion battery cells this should reduce drudgery and protect the farmers from harmful pesticides and other chemicals. 


\subsection{Laboratory tests results}

The results of the laboratory tests on the robot electronic components, as well as the programming of the microcontroller unit, showed that the robot executed through its programming all the commands as explained in Flowchart in Figure (6).

Figure (11) shows the relationship between time elapsed starting from the start of robot operation, when the battery capacity is full, $(12.07 \mathrm{~V}-2.8 \mathrm{Ah}$ - $33.8 \mathrm{Wh}$ ) to reach the insufficient battery capacity to operate the robot components $(9.51 \mathrm{~V}-1.49 \mathrm{Ah}-14.17 \mathrm{Wh})$. The battery minimum state of charge (SOC) is a relative value below which the storage bank is never drawn, specified as a percentage of the total capacity. In our case, as presented in Figure (12), the minimum SOC recorded is $41.92 \%$. This is comparable to the expected range. Most rechargeable batteries are not meant to be fully discharged. In fact, fully discharging some batteries can permanently damage them. The minimum SOC is typically set to $30-50 \%$ in order to avoid damaging the storage bank by excessive discharge (He et al., 2013; Peng, 2014; Zhang et al., 2018).

The calculated consumed energy by DC motors and the sprayer electric pump is $19.63 \mathrm{~W}$ during $8.91 \mathrm{~min}$ of operation at full load. This reflects the energy availability of battery capacity which exceeded $58.08 \%$. The results in Figure (11) showed the consumed amount of energy by DC-motor and the sprayer electric pump were comparable to the theoretical values described in the component's datasheets. This proves the reliability of the robot's power supply unit design, which qualifies it to be used as is in a prototype production. Additional modification will be necessary only if new functions are needed or different components were used.

The spray area coverage test results recorded $70.2 \%$ as average. Figure (13) shows that, spray coated the surface in adequate and consistent dosage. However, this value is pump pressure head $\left(h_{\text {pump }}\right)$ dependent. The $h_{\text {pump }}$ decreased gradually as $V_{p}$ decreased (Fig. 14). That led to subsequent decrease in nozzle discharge $\left(\mathrm{Q}_{\text {nozzle }}\right)$ and the coverage area. When $\mathrm{V}_{\mathrm{p}}$ $\geq 8.6 \mathrm{~V}$, the $\mathrm{h}_{\text {pump}}$, Qnozzle, and coverage area recorded $30 \mathrm{~m}, 0.335 \mathrm{~L} / \mathrm{min}$, and $91.0 \%$ respectively. 


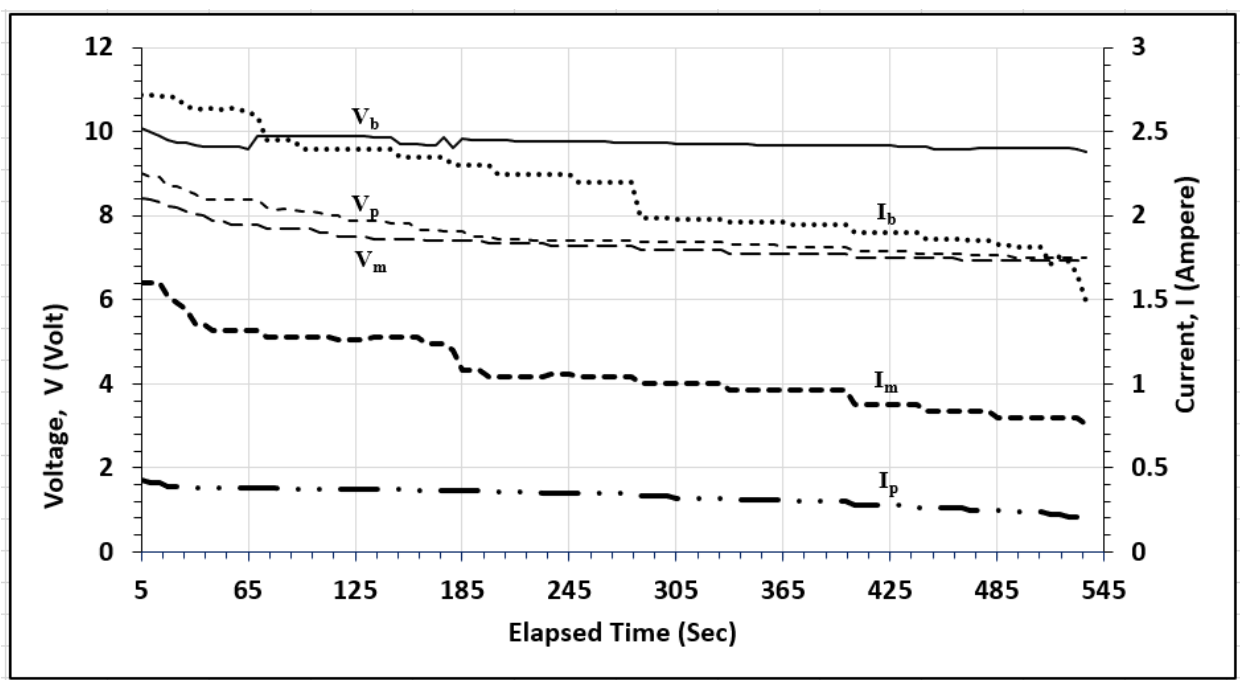

Fig. 11: Relationship between elapsed time and voltage and current of the robot main components (battery $\mathrm{V}_{\mathrm{b}} \& \mathrm{I}_{\mathrm{b}}$, sprayer electric pump $\mathrm{V}_{\mathrm{p}}$ $\& \mathrm{I}_{\mathrm{p}}$, and DC motors $\mathrm{V}_{\mathrm{m}} \& \mathrm{I}_{\mathrm{m}}$ ).

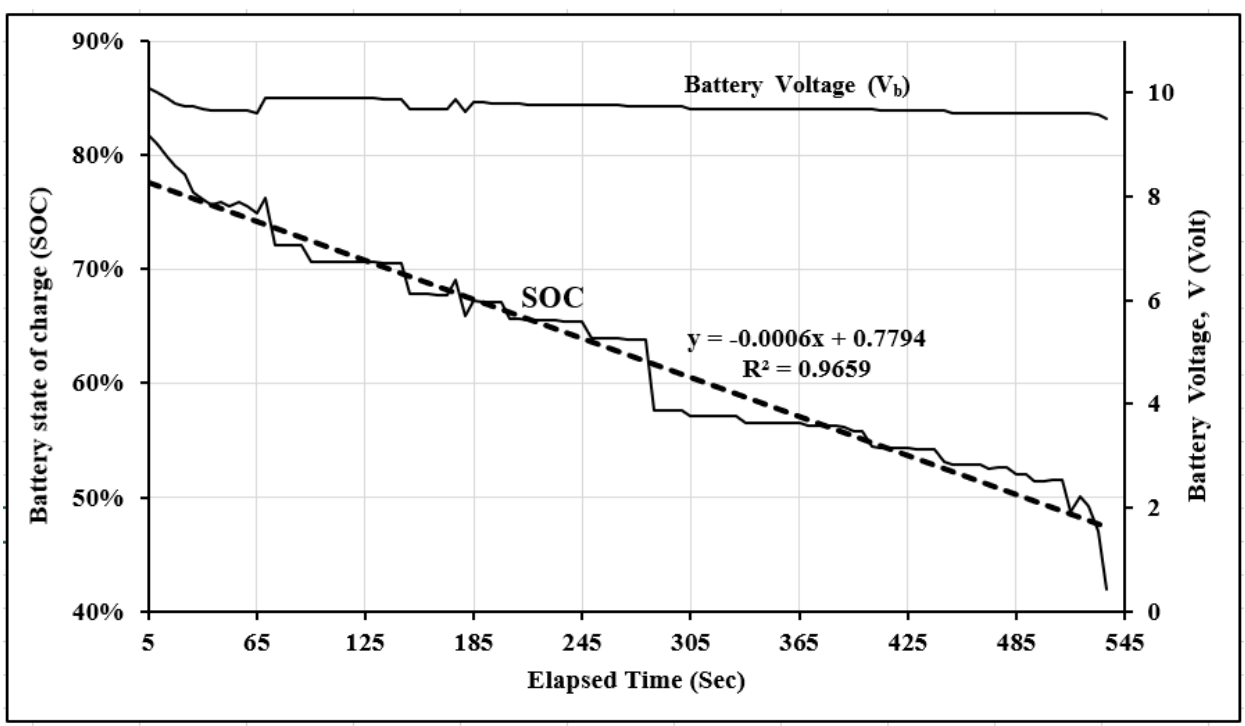

Fig. 12: Relative state of charge (SOC) in relation to battery volt and Time.

Subsequent decrease in all parameters was recorded as $\mathrm{V}_{\mathrm{p}}$ was decreased during operation. Coverage area reached $50 \%$ when $\mathrm{V}_{\mathrm{p}}=7.1 \mathrm{~V}$ and the minimum value of $25.0 \%$ as $\mathrm{V}_{\mathrm{p}}$ reached $7.0 \mathrm{~V}$. then the electric pump failed. 
This is comparable to the work of Sammons et al. (2005), they reported the importance of consistent coverage of plants in spray test. The spray ratio can be regulated according to the application needs by controlling the pressure, flow rate and robot speed. However, the consistence coverage reflects the efficiency of the robot model as agrochemical sprayer.

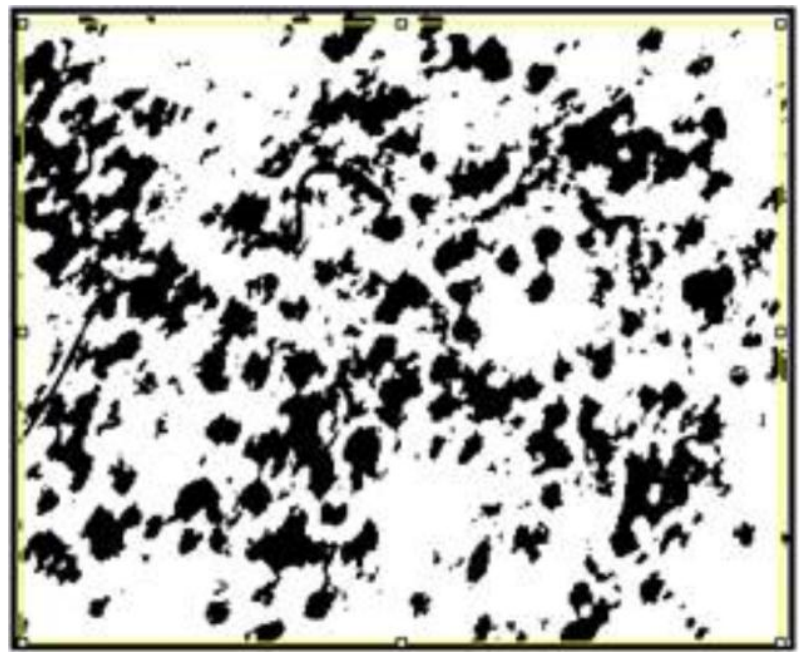

Fig. 13: White filter paper sprayed with blue water using the robot model.

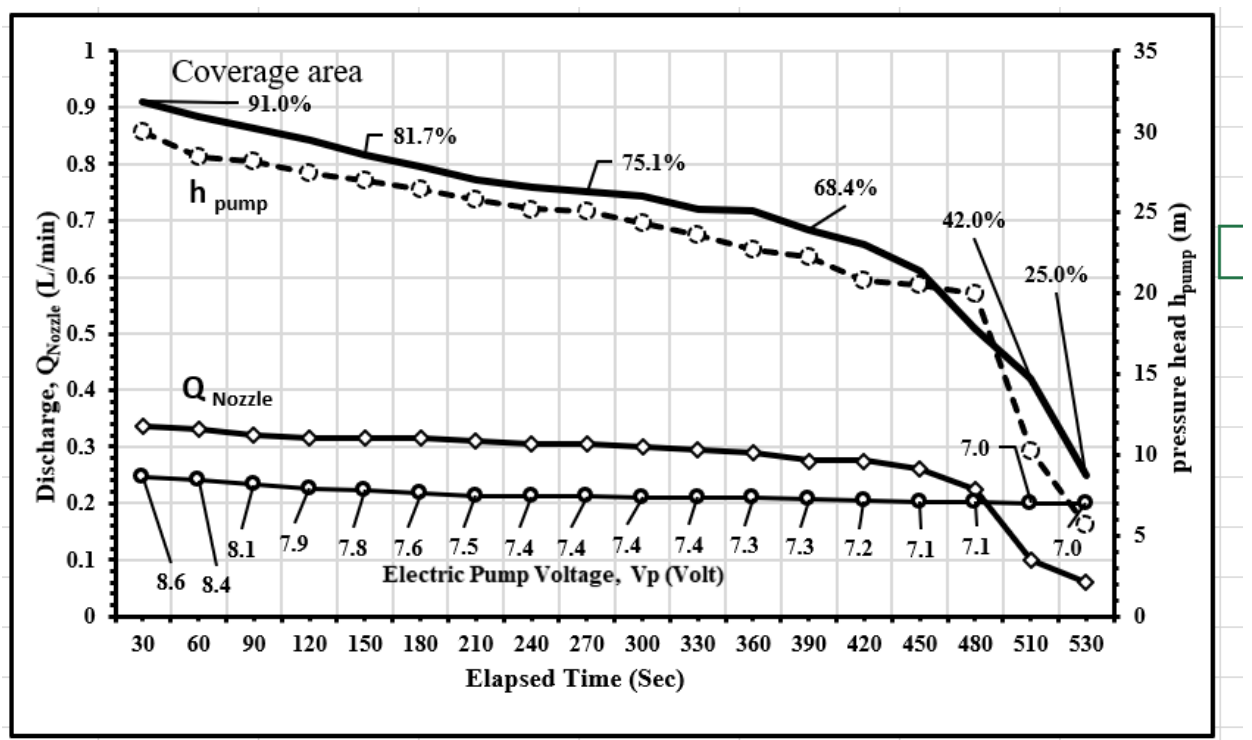

Fig. 14: Relation between electronic pump voltage and single nozzle discharge, pump pressure head, and coverage area. 
Based on the experiments performed, it is found that the solar panel used provides $12 \mathrm{~V}, 4.5 \mathrm{Ah}$ and $24 \mathrm{~W}$. The scarcity of power can be overcome by this, on the other hand, the battery is rechargeable by supply available at homes. However, the effective working time will be extended under continues solar charging (during daytime). Further work should be done to estimate the maximum operating range under various environmental conditions in the prototype production stage. The preliminary results obtained in this study for the evaluation of the constructed robot model indicated the proper and trustable operation of it for greenhouses applications as described by Rafiq et al. (2014).

Taking all together, this robot model allows the manual labor elimination within greenhouses during agrochemical spray. Constant and effective discharge is achieved which eventually increases productivity. There are no health hazards to the operator. These results are fulfilling the criteria required for such model which were specified in the aim of this study and by other researchers' in the resents years (Chavan et al., 2015; Nithin et al., 2016; Sharma and Borse, 2016; Adamides et al., 2017a; Adamides et al., 2017b; Londhe and Sujata, 2017; Poudel et al., 2017).

\section{CONCLUSION}

The presented robot design concept and its successful constructed model using available commercial components can be built via a simple and costeffective manner. It undertakes the task of autonomously spraying agrochemicals within greenhouses effectively and safely. Further work needs to be continued to scale up this model to be feasibly working prototype in real conditions.

\section{ACKNOWLEDGMENT}

My sincere thanks to Prof. Dr. Ahmed El-Sayed - Agricultural and Biosystems Engineering Department, Faculty of Agriculture، Alexandria University, Egypt for his valuable assistance reviewing this work. My gratitude to Dr. Mustafa Elnainay - Associate Professor of Computer Engineering, Computer and Systems Engineering Department, Faculty of Engineering, Alexandria University, Egypt for his significant technical support. 


\section{REFERENCES}

Adamides G., Katsanos C., Constantinou I., Christou G., Xenos M., Hadzilacos T. and Edan Y. (2017a) Design and development of a semi-autonomous agricultural vineyard sprayer: Human-robot interaction aspects. Journal of Field Robotics 34:1407-1426.

Adamides G., Katsanos C., Parmet Y., Christou G., Xenos M., Hadzilacos T. and Edan Y. (2017b) HRI usability evaluation of interaction modes for a teleoperated agricultural robotic sprayer. Applied ergonomics 62:237-246.

Aldrich R.A. and Bartok J.W. (1994) Greenhouse engineering Northeast Regional Agricultural Engineering Service Ithaca, NY.

Amarapur B. (2013) Multiple Power Supplied Fertilizer Sprayer. International Journal of Scientific and Research Publications 3:1.

Andi Co. (2018) Arduino Bluetooth RC Car, Google LLC.

Berenstein R. and Edan Y. (2017) Human-robot collaborative site-specific sprayer. Journal of Field Robotics 34:1519-1530.

Berenstein R. and Edan Y. (2018) Automatic adjustable spraying device for site-specific agricultural application. IEEE Transactions on Automation Science and Engineering 15:641-650.

Boxall J. (2014) L298N Dual Motor Controller Module 2A and Arduino, in: Tronixlabs (Ed.), Australia.

Charvani S., Sowmya K., Malathi M., Rajani P. and Saibaba K. (2017) Design and Fabrication of a Solar Sprayer. International journal of science technology and management 6:589-596.

Chavan R., Hussain A., Mahadeokar S., Nichat S. and Devasagayam D. (2015) Design and construction of solar powered agricultural pesticide sprayer. International Journal of Innovations \& Advancement in Computer Science 4:145-150.

Datasheet 1. (2016) 25D mm Metal Gearmotors (without encoders), in: P. R. Electronics (Ed.), Pololu Corporation, Las Vegas, Nevada, USA. 
Datasheet 2. (2018) Dagu Wild Thumper Wheel 120x60mm Pair with 4mm Shaft Adapters - Chrome, in: P. R. Electronics (Ed.), Wheels, Tracks, and Ball Casters, Pololu Corporation, Las Vegas, Nevada, USA.

Datasheet 3. (2018) ATmega 48A/PA/88A/PA/168A/PA/328/P -AN- 8 Bit Microcontroller Datasheet, in: M. T. Inc. (Ed.), megaAVR® Data Sheet, Arizona, USA.

Datasheet 4. (2003) Linear Li-Ion Battery Charger with Thermal Regulation in ThinSOT, in: L. T. Corporation (Ed.), California, USA.

Datasheet 5. (2008) Lithium-ion Rechargeable Cell Model : ICR1865028A, in: S. S. C. Ltd. (Ed.), Specification of Product, Kyungki-Do, Korea.

Datasheet 6. (2010) HC-06 Bluetooth to Serial Port Module, in: I. Studio (Ed.), Electrónica Estudio, Centro, México.

Datasheet 7. (2011) Module Data Sheet - HC-06, in: L. Guangzhou HC Information Technology Co. (Ed.), Guangzhou. pp. 17.

Datasheet 8. (2017) Fully Integrated, Hall Effect-Based Linear Current Sensor IC with $2.1 \mathrm{kVRMS}$ Isolation and a Low-Resistance Current Conductor in: L. Allegro MicroSystems (Ed.), Allegro MicroSystems, LLC Massachusetts, USA.

Datasheet 8. (2018) Battery Powered Automatic Pressure Switch Type 15w 1.51/min 12v DC Mini Water Pump, in: 1. Ningbo Nuolin Mechatronics co. (Ed.), Diaphragm Pump, Zhejiang, China.

Datasheet 9. (2004) Positive-Voltage Regulators, in: T. I. Incorporated (Ed.), $\mu$ A7800 SERIES Texas Instruments Incorporated, Texas, USA.

Datasheet 9. (2017) Bourdon tube pressure gauge, copper alloy Standard version Models 111.10, 111.12. , in: W. I. Corporation (Ed.), Mechanical pressure measurement, WIKA Instrument Corporation, Klingenberg, Germany.

Datasheet 10. (2008) Spacifications of LCD module, in: L. Xiamen Amotec Display Co. (Ed.), Xiamen Amotec Display Co.,Ltd, Xiamen, China. 
Deng S., Cai Z., Fang D., Liao H. and Montavon G. (2012) Application of robot offline programming in thermal spraying. Surface and Coatings Technology 206:3875-3882.

Dongare A., chavan S., Nirve S., Arabale P. and Suryawanshi U. (2017) Agriculture based robot (AGRIBOT). Internation Journal Of Advance Research And Innovative Ideas In Education 3:1416-1420.

Egypt's Sisi inaugurates water-preserving national greenhouse project. (2018), Ahram Online, Ahram Online, Ciro.

Grisso R.D., Hipkins P.A., Askew S., Hipkins P.L. and McCall D.S. (2013) Nozzles: selection and sizing.

He Y., Liu X., Zhang C. and Chen Z. (2013) A new model for State-ofCharge (SOC) estimation for high-power Li-ion batteries. Applied Energy 101:808-814.

iChano Inc. (2018) AtHome Camera iChano Incorporation, Canada. pp. Home security video surveillance.

ISIS User Manual. (2002), in: L. Electronics (Ed.), Intelligent Schematic Input System Labcenter Electronics, Skipton, UK.

King A. (2017) The future of agriculture. Nature 544:S21-S23.

Klein R.N. and Kruger G.R. (2011) Nozzle-Selection and Sizing, in: I. A. a. N. R. University of Nebraska- Lincoln Extension (Ed.).

Londhe S.B. and Sujata K. (2017) Remotely Operated Pesticide Sprayer Robot in Agricultural Field. International Journal of Computer Applications (0975-8887) Volume:26-29.

Nithin, J S.K., Kripa, P V. and V A. (2016) Automatic Pesticides Spraying Robot using Machine Vision Technique. International Journal of Advanced Research in Computer Science and Software Engineering 6:228-232.

Pahuja R. and Kumar N. (2014) Android Mobile Phone Controlled Bluetooth Robot Using 8051 Microcontroller. International Journal of Scientific Engineering and Research 2:14-17. 
Patil A., Reddy H., K R., K S.O. and B.S N. (2017) An Innovative Approach to Control Pesticide Sprayer Using Solar Based Bluetooth Device. International Journal of Advanced Research in Electrical, Electronics and Instrumentation Engineering 6:4098-4101.

Peng J. (2014) Multi-Robot Systems Design and Implementation Based On Psoc5. Open Automation and Control Systems Journal 6:1189-1196.

Poudel B., Sapkota R., Shah R.B., Subedi N. and GL A.K. (2017) Design and Fabrication of Solar Powered Semi Automatic Pesticide Sprayer.

Rafiq A., kalantari D. and Mashhadimeyghani H. (2014) Construction and development of an automatic sprayer for greenhouse. Agricultural Engineering International: CIGR Journal 16:36-40.

Sammons P.J., Furukawa T. and Bulgin A. (2005) Autonomous pesticide spraying robot for use in a greenhouse, Australian Conference on Robotics and Automation. pp. 1-9.

Shamshiri R.R. and Hameed I.A. (2018) Fundamental Research on Unmanned Aerial Vehicles to Support Precision Agriculture in Palm Oil Plantations.

Shamshiri R.R., Weltzien C., Hameed I.A., Yule I.J., Grift T.E., Balasundram S.K., Pitonakova L., Ahmad D. and Chowdhary G. (2018) Research and development in agricultural robotics: A perspective of digital farming. International Journal of Agricultural and Biological Engineering 11:1-14.

Sharma S. and Borse R. (2016) Automatic Agriculture Spraying Robot with Smart Decision Making, The International Symposium on Intelligent Systems Technologies and Applications, Springer. pp. 743-758.

Yan M. and Shi H. (2013) Smart living using Bluetooth-based Android smartphone. International Journal of Wireless \& Mobile Networks 5:65.

Zhang R., Xia B., Li B., Cao L., Lai Y., Zheng W., Wang H. and Wang W. (2018) State of the Art of Lithium-Ion Battery SOC Estimation for Electrical Vehicles. Energies 11:1820. 


\section{المخلص العربي}

\section{نموذج رويوت زراعي: تطوير رشاش مدمج يعمل بالطاقة الثمسية}

\section{عبد العزيز إبراهيم عمارة}

لا يمكن للزر اعة المصــرية أن تواجه التحديات الحديثة دون إدخال التكنولوجيا المحلية لـهذه

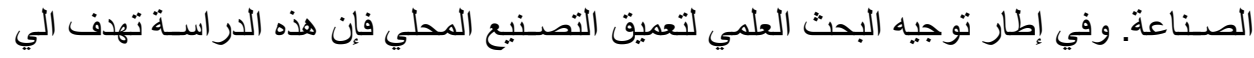
تطوير وتقيم نموذج لروبوت زر اعي يعمل بالطاقة الثــمســية لرش المو اد الكميائية والمبيدات

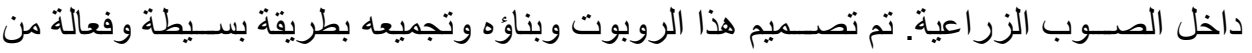
حيث التكلفة من مكونات رئيسية وبرمجيات نشـغيل وكذلك اجهزة اختبار للنتائج النهائية جميعها بونها

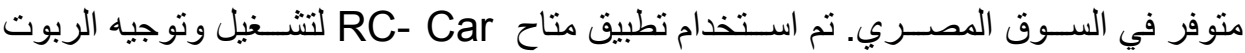

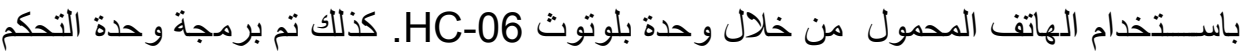

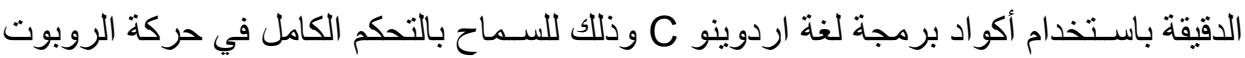

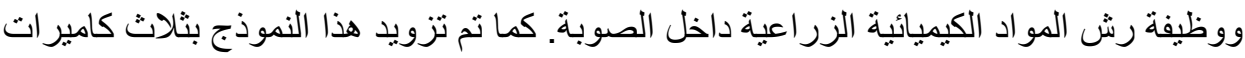

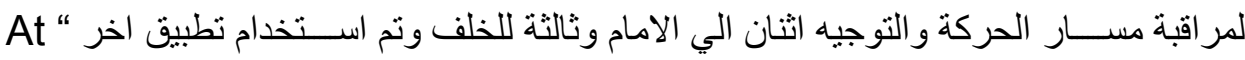
"Home Camera

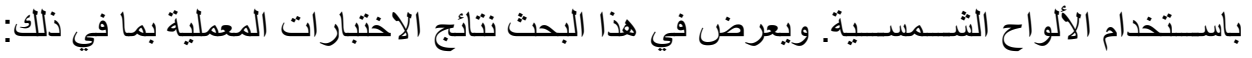

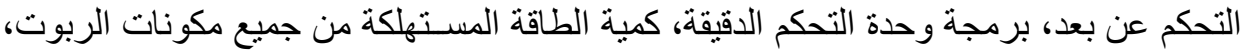

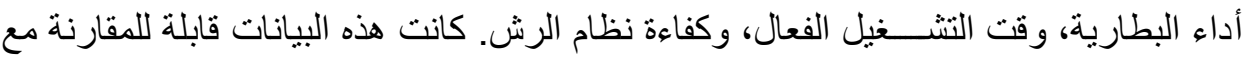
القيم المرجعية ومنوافقة مع المعايير المطلوبة لاداء المهام المستهدفة. و هذا يثبت موثوقية تصميم

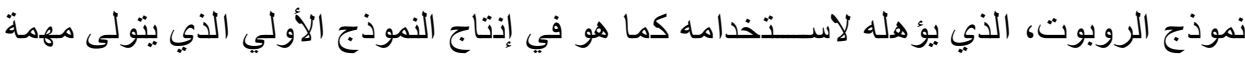
الرش الذاتي للكيماويات الزر اعية في البيوت المحمية بلهعالية وأمان.

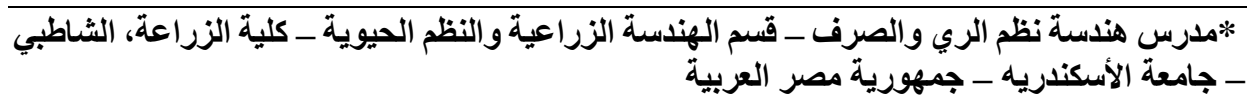

